\title{
Smear layer removal capacity of disinfectant solutions used with and without EDTA for the irrigation of canals: a SEM study
}

\section{Capacidade de remoção da "smear layer" de soluções desinfetantes, usados com ou sem EDTA, na irrigação de canais: estudo por MEV}

Ana Carolina Silveira Cardoso de Menezes*

Caio Gorgulho Zanet**

Márcia Carneiro Valera***

\begin{abstract}
The purpose of this study was to carry out a scanning electron microscopic (SEM) analysis of the cleaning qualities and smear layer removal from root canal walls, instrumented and irrigated with $2.5 \% \mathrm{NaOCl}, 2.0 \%$ chlorhexidine and saline solutions. Fifty extracted teeth were used in this study. All teeth were radiographed to determine the existence of a single canal. The crowns were cut at the cervical limit and the root canals were instrumented with K-type files up to size 45. During root canal preparation, irrigations were made with the different solutions being evaluated: Group 1: 2.5\% NaOCl (10 roots); Group 2: $2.5 \% \mathrm{NaOCl}$ and 17\% EDTA for 2 minute (10 roots); Group 3: 2.0\% chlorhexidine (10 roots); Group 4: $2.0 \%$ chlorhexidine and 17\% EDTA for 2 minutes (10 roots); Group 5: saline solution (5 roots); Group 6: saline solution and 17\% EDTA for 2 minutes (5 roots). After instrumentation, the canals were irrigated with each one of the solutions and the roots were cut in the buccolingual direction for SEM analysis, at the cervical, middle and apical thirds, to ascertain the presence or absence of smear layer and debris. SEM analysis was performed by three calibrated examiners and scores were submitted to Kruskal-Wallis test at the significance level of $p=5 \%$. Results showed that the use of $17 \%$ EDTA decreased the smear layer significantly $(p<0.05)$ for all evaluated solutions in all thirds. When EDTA was not used, a significantly higher quantity of smear layer on the apical third was observed only in the $\mathrm{NaOCl}$ groups. The use of $17 \%$ EDTA was significant for debris removal except for the chlorhexidine groups. The following conclusion could be drawn: the use of $17 \%$ EDTA was necessary to enhance cleanness of the root canals.
\end{abstract}

DESCRIPTORS: Smear layer; Sodium hypochlorite; Chlorhexidine; EDTA; Root canal irrigants.

\begin{abstract}
RESUMO: Este estudo propôs avaliar, através da microscopia eletrônica de varredura (MEV), a capacidade de limpeza e remoção de "smear layer" e debris das paredes de canais radiculares preparados e irrigados com soluções de hipoclorito de sódio $(\mathrm{NaOCl})$ a $2,5 \%$, gluconato de clorexidina (CLX) a 2,0\% e soro fisiológico (controle). Utilizaram-se 50 dentes unirradiculares extraídos com um único canal. Cortaram-se as coroas no limite cervical e os canais foram preparados até o instrumento 45. Durante o preparo foram feitas irrigações com as soluções a serem avaliadas: Grupo 1: $\mathrm{NaOCl}$ a 2,5\% (10 raízes); Grupo 2: $\mathrm{NaOCl}$ a 2,5\% seguido de irrigação com EDTA a 17\% por 2 minutos (10 raízes); Grupo 3: CLX a 2,0\% (10 raízes); Grupo 4: CLX a 2,0\% e EDTA a 17\% por 2 minutos (10 raízes); Grupo 5: soro fisiológico (5 raizes); Grupo 6: soro físiológico e EDTA a 17\% por 2 minutos (5 raizes). Após o preparo, os canais foram irrigados com as soluções em teste, e as raízes cortadas no sentido V-L para avaliação por MEV, nos terços cervical, médio e apical, verificando-se a presença de "smear layer" e debris. Os dados relativos aos escores atribuídos foram avaliados pelo teste Kruskal-Wallis com $\mathrm{p}=5 \%$. Os resultados mostraram que o uso do EDTA diminuiu significativamente $(p<0,05)$ a "smear layer" para todas as soluções avaliadas em todos os terços. Quando não se utilizou o EDTA, somente para o grupo do $\mathrm{NaOCl}$, verificou-se quantidade significativamente maior de "smear layer" no terço apical. Exceto para a CLX, o uso de EDTA diminuiu significativamente a quantidade de debris. Concluiu-se, que após o preparo, faz-se necessária a utilização do EDTA a fim de promover melhor limpeza das paredes dos canais radiculares.
\end{abstract}

DESCRITORES: Camada de esfregaço; Hipoclorito de sódio; Clorexidina; EDTA; Irrigantes do canal radicular.

\section{INTRODUCTION}

One of the main purposes of Endodontic therapy is to disinfect the root canal, which is accom- plished by removing the pulp tissue or necrotic pulp remnants, any microorganisms present in the root canal system and infected dentin. However, the smear layer is formed during root prepa-

* Trainee in Pediatric Dentistry; **MSc in Restorative Dentistry; ***Associate Professor in Endodontics - School of Dentistry of São José dos Campos, São Paulo State University. 
Menezes ACSC, Zanet CG, Valera MC. Smear layer removal capacity of disinfectants solutions used with and without EDTA for the irrigating of canals: a SEM study. Pesqui Odontol Bras 2003;17(4):349-55.

ration. The smear layer is composed of dentin debris, organic material and microorganisms that adhere to the root canal walls obstructing the openings of the dentin tubules, which can hinder the action of medicine in the dentin tubules and root canal system. Removal of this layer is important for the success of the endodontic treatment and is obtained with the use of chemical solutions during root preparation ${ }^{8}$.

The sodium hypochlorite solution $(\mathrm{NaOCl})$ has been the mostly used irrigant for over four decades, due especially to its effective antibacterial properties and its excellent action as an inorganic material solvent. However, $\mathrm{NaOCl}$ is considered toxic to the periapical tissues, especially when used in high concentrations $s^{5,11}$

Chlorhexidine gluconate is an effective oral antimicrobial agent for periodontal therapy, caries prevention and endodontic irrigation ${ }^{13,16}$ since it possess broad-spectrum antimicrobial action, substantivity, and is non toxic. However, it is not a tissue solvent ${ }^{11}$, and debris can remain adhered to root walls, obstructing the dentinal tubules.

The purpose of this study was to use scanning electron microscopy (SEM) to evaluate the removal of the smear layer from the root canal walls prepared and irrigated with $2.5 \%$ sodium hypochlorite and $2.0 \%$ chlorhexidine gluconate, associated or not to $17 \%$ EDTA.

\section{MATERIAL AND METHODS}

Fifty human teeth, extracted for different reasons in the surgery clinic of the School of Dentistry of São José dos Campos, São Paulo State University (UNESP), were used with previous authorization from the patients.

The teeth were externally cleaned, the crowns were cut at the cementoenamel junction, and the roots were X-rayed in the proximal direction with periapical intraoral film (Ektaspeed plus -EP-21P, size 2, Kodak, New York, USA) to determine the existence of a single canal. Before preparation the roots were randomly divided into four experimental groups with 10 roots each, and two control groups with five roots each. The experimental groups were irrigated with $2.5 \% \mathrm{NaOCl}$ (Farmácia Homeoterápica da Lozzo Ltda., SP, Brasil) (Group 1); 2.5\% NaOCl and 17\% EDTA (Farmácia Homeoterápica da Lozzo Ltda., SP, Brasil) (Group 2); 2.0\% chlorhexidine gluconate (Farmácia Homeoterápica da Lozzo Ltda., SP, Brasil) (Group 3); and 2.0\% chlorhexidine gluconate and
17\% EDTA (Group 4). The control groups were irrigated with sterile physiological saline solution (Farmácia Homeoterápica da Lozzo Ltda., SP, Brasil) (Group 5) and sterile physiological saline solution and 17\% EDTA (Group 6).

Working lengths were established $0.5 \mathrm{~mm}$ short of the anatomical apex by visually identifying a \#10 K-file at the apical foramina. The roots were instrumented up to \#45 K-file and were irrigated with $5 \mathrm{ml}$ of the irrigating solution at each change of instrument. In Groups 2, 4 and 6, after preparation, the roots were irrigated with $3 \mathrm{ml}$ of $17 \%$ EDTA for two minutes, followed by $5 \mathrm{ml}$ of the solution used during instrumentation. The irrigants were taken to the canals with a 27-gauge endodontic irrigating needle (Becton Dickinsonind Cirúrgica Ltda., Juiz de Fora, Brazil) and placed in the entire root canal extension.

With a diamond disk (Microdont, São Paulo, Brazil) two sulci along the external root surface were made in the buccolingual direction and the teeth were split in half using a chisel to expose the root canal. The roots were mounted on stubs, put in a vacuum chamber, sputter coated with gold-palladium 20 to $25 \mathrm{~nm}$ thick with a sputter coater (Farmácia Homeoterápica da Lozzo Ltda., SP, Brasil) for SEM evaluation (JEOL, JSM 5310 Japan). The cervical, middle and apical thirds of the root canal were evaluated at $500 \mathrm{X}$ and 2,000 X magnification. Standard photomicrographs representing each root third for each sample were taken for topography evaluation of the root walls. The amount of smear layer was graded from 0 to 3 $(0=$ no smear layer with all tubules open; $1=$ minimal quantity of smear layer with over $50 \%$ tubules open; 2 = moderate quantity of smear layer with less than $50 \%$ tubules open; $3=$ heavy smear layer with almost all dentin tubules obstructed). SEM analysis was performed by three standardized examiners and the scores were statistically evaluated using the Kruskal-Wallis test at the significance level of $\mathrm{p}>0.05$. For comparison between groups, the Median test was used at the significance level of $\mathrm{p}>0.05$.

\section{RESULTS}

A total of 300 photomicrographs were taken from the cervical, middle and apical thirds of the root canals. 
Menezes ACSC, Zanet CG, Valera MC. Smear layer removal capacity of disinfectants solutions used with and without EDTA for the irrigating of canals: a SEM study. Pesqui Odontol Bras 2003;17(4):349-55.

\section{$\mathbf{2 . 5} \%$ sodium hypochlorite group}

The $\mathrm{NaOCl}$ did not remove the smear layer of the middle and apical thirds (Figure 1 - B, C); however, the cervical third presented less quantity of smear layer covering the dentin walls and a greater number of exposed dentin tubules (Figure 1 - A). When EDTA was used, it was verified that the tubules were unobstructed at the cervical, middle and apical thirds (Figure $1-\mathrm{D}, \mathrm{E}, \mathrm{F}$ ).

\section{0\% chlorhexidine gluconate group}

The $2.0 \%$ chlorhexidine gluconate was not capable of removing the smear layer that remained attached to the dentin walls. In a few regions, some open dentin tubules could be observed (Figure 2 A - cervical; B - middle; C - apical). After the use of EDTA, a better cleaning, exposing the dentin tubules, was observed, but with some debris similar to crystals spread on the dentin surface (Figure 2 D - cervical; E - middle; F - apical).

\section{Control group (physiological solution)}

The dentin wall of the specimens irrigated only with physiological solution were completely covered with smear layer on the cervical, middle and apical thirds after biomechanical preparation (Figure 3 - A - cervical; B - middle; C - apical). When EDTA was used as the final irrigating solution, the smear layer was removed in the entire extension of the root canal, including the apical third (Figure 3 D - cervical; E - middle; F - apical).

Graphs 1 and 2 show the distribution of scores observed in the experimental and control groups.

Comparative statistical analysis showed no statistical difference between groups with and without the use of EDTA ( $p>0.05)$. Although without significant statistical differences, when EDTA was used, the $2.5 \% \mathrm{NaOCl}$ and $2.0 \%$ chlorhexidine
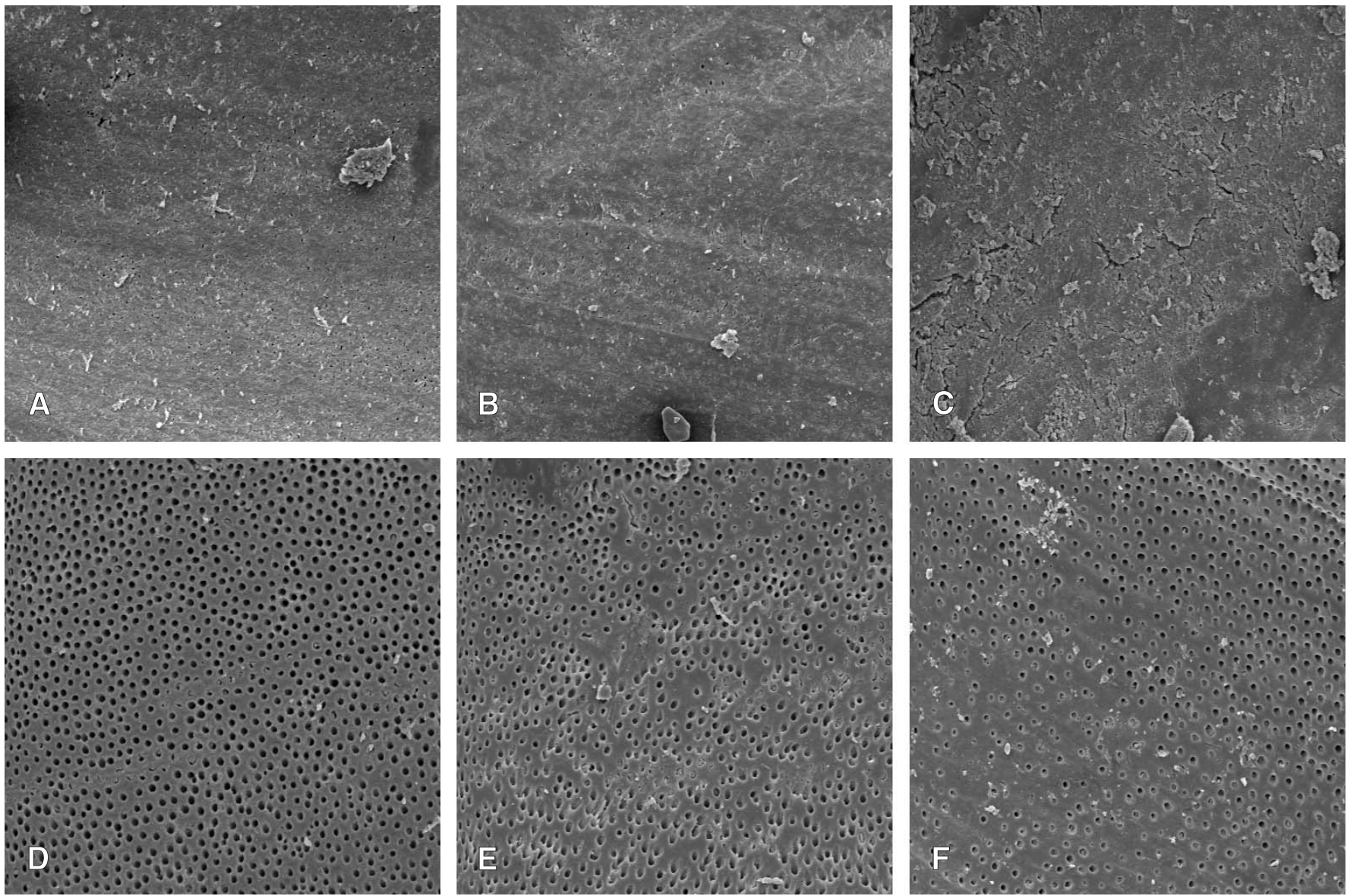

FIGURE 1 - A - cervical, B - middle, C - apical (2.5\% NaOCl without EDTA); D - cervical, E - middle, F - apical (2.5\% $\mathrm{NaOCl}$ with EDTA). 

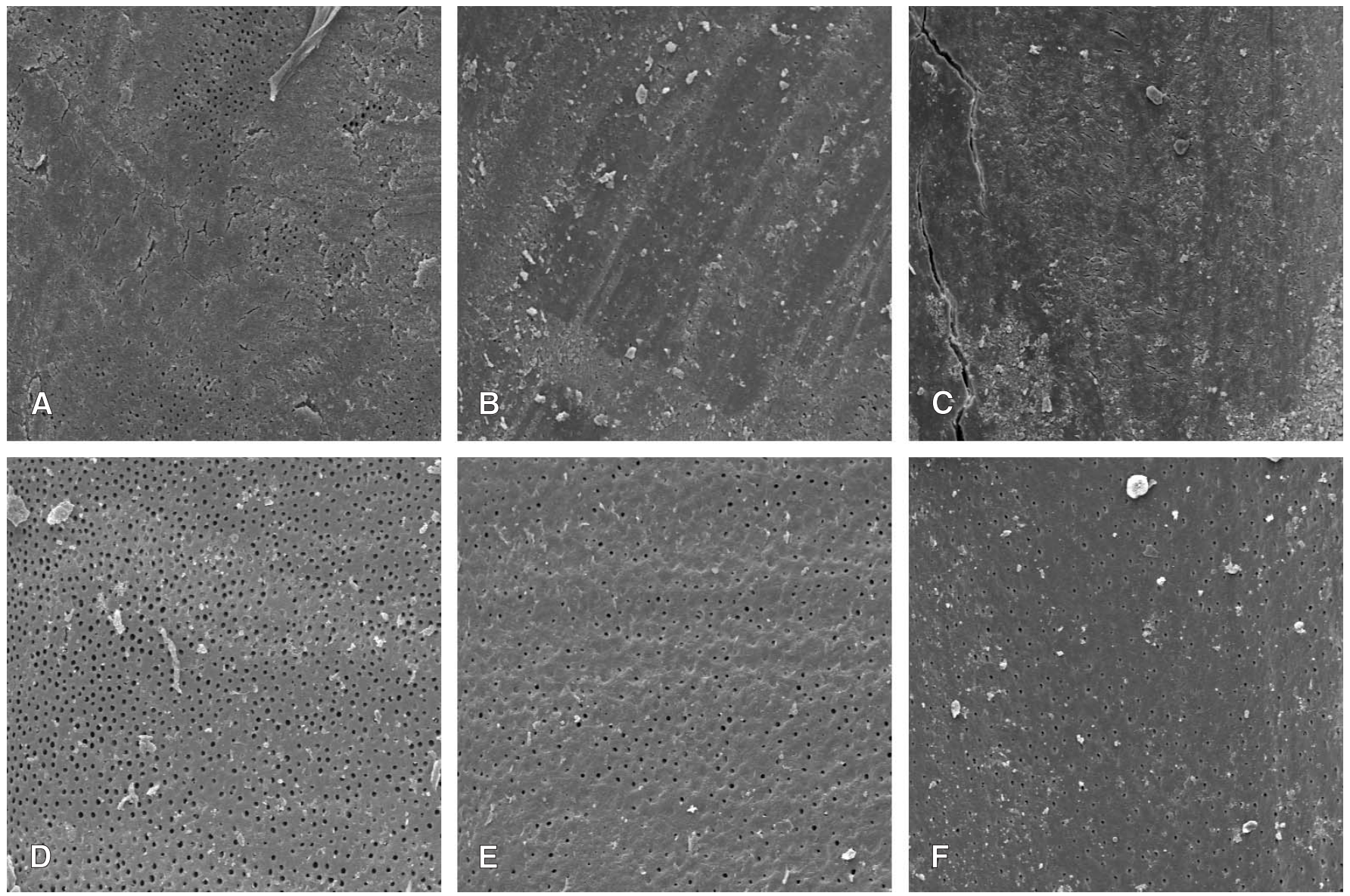

FIGURE 2 - A - cervical, B - middle, C - apical (2.0\% chlorhexidine gluconate without EDTA); D - cervical, E - middle, F apical $(2.0 \%$ chlorhexidine gluconate with EDTA).

gluconate solutions removed the smear layer better $(83 \%$ and $80 \%$, respectively) than the control group (53\%).

As for the cervical, middle and apical thirds without EDTA, the control and $2.0 \%$ chlorhexidine groups were not statistically different $(p=0.17$ and 0.05 respectively). However, the cervical third presented less quantity of smear layer then the apical third when $2.5 \% \mathrm{NaOCl}$ was used ( $\mathrm{p}=0.0068)$. There was no significant statistical difference between the cervical, middle and apical thirds when $17 \%$ EDTA was used, regardless of the irrigating solution used $(2.5 \% \mathrm{NaOCl}-\mathrm{p}=0.75 ; 2.0 \%$ chlorhexidine gluconate $-\mathrm{p}=0.54$; physiological saline solution $-\mathrm{p}=0.62)$.

\section{DISCUSSION}

The results of this study show that $2.5 \%$ sodium hypochlorite and $2.0 \%$ chlorhexidine gluconate did not promote an adequate cleaning of the root canal with great quantity of smear layer remaining adhered to the dentin walls.

According to Baumgartner, Mader ${ }^{2}$ (1987), the smear layer deposited on the canal walls after instrumentation is caused by the direct action of the instruments on the dentin walls that shift the organic and inorganic debris, polishing them and forming an amorphous smear layer.

The removal of the smear layer and smear plug is extremely important, especially in teeth with pulp necrosis, due to the presence of bacteria, in order to facilitate root canal dressing ${ }^{3}$. Moreover, the smear layer influences on the root canal obturation sealing, since its presence interferes in the adhesion of the obturating material to the dentin walls ${ }^{8,10}$.

The results of this work corroborate preceding studies that verified that final irrigation with $17 \%$ EDTA removes the smear layer effectively. Goldberg, Abramovich ${ }^{8}$ (1977) verified that even in 
Menezes ACSC, Zanet CG, Valera MC. Smear layer removal capacity of disinfectants solutions used with and without EDTA for the irrigating of canals: a SEM study. Pesqui Odontol Bras 2003;17(4):349-55.
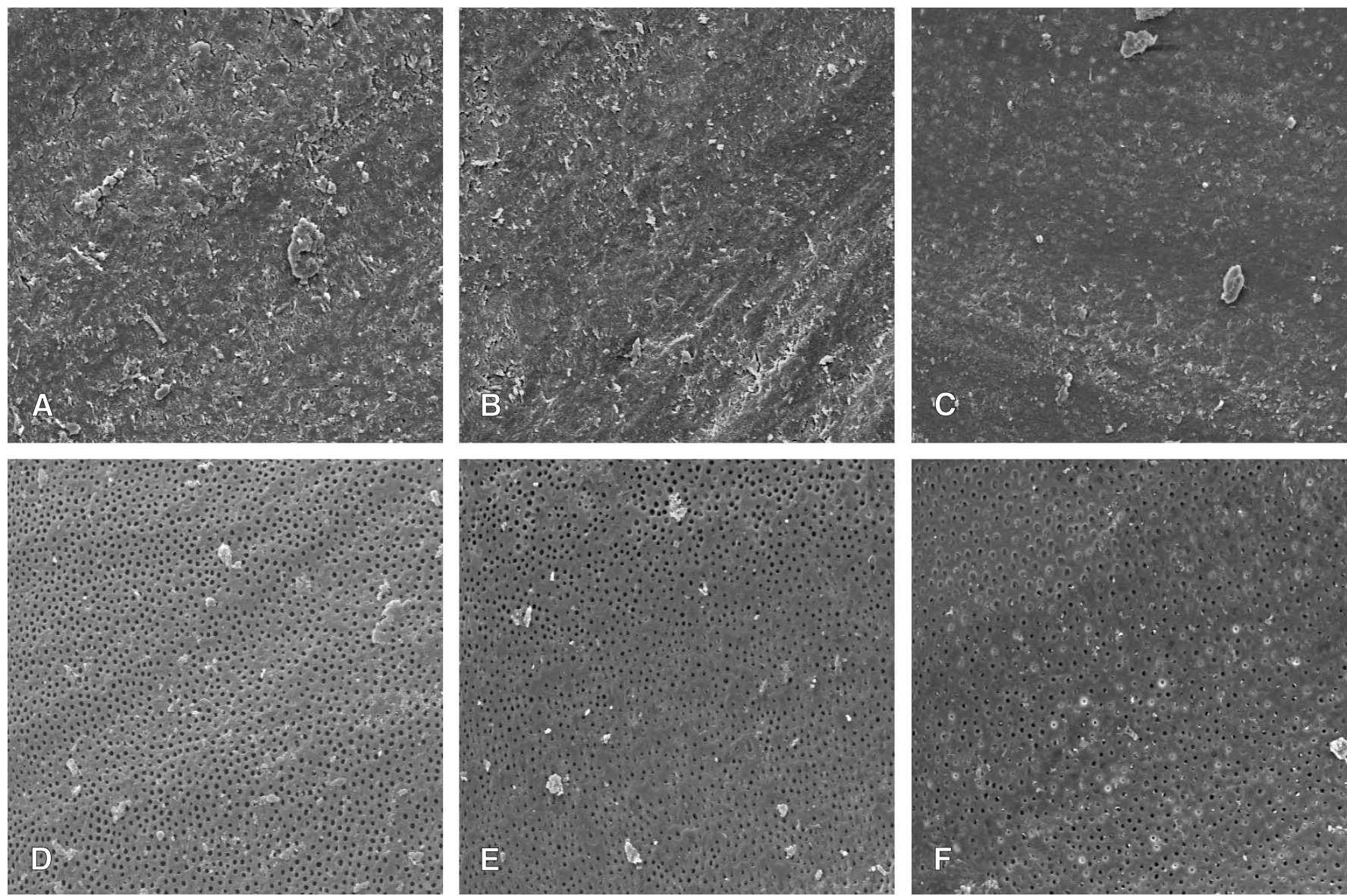

FIGURE 3 - A - cervical, B - middle, C - apical (physiological solution without EDTA); D - cervical, E - middle, F - apical (physiological solution with EDTA).

canals irrigated with physiological saline solution, the use of EDTA for 15 minutes after preparation promoted an effective cleaning of the dentin walls. Tatsuta et al. ${ }^{15}$ (1999) used $5.25 \% \mathrm{NaOCl}$ and $15 \%$ EDTA alternately, and observed an effective removal of the smear layer, predentin and pulp debris. The chelating effect of EDTA demineralizes and removes the inorganic components of the smear layer produced during instrumentation, leaving an organic fibrous component on the canal walls ${ }^{2}$. When combining $\mathrm{NaOCl}$, which is an organic solvent, and EDTA, Baumgartner, Mader ${ }^{2}$ (1987) verified complete removal of the residual layer after instrumentation, for this layer is composed of organic material ${ }^{4}$. Studies of Franchi et al. ${ }^{6}$ (1992) showed that $\mathrm{NaOCl}$ was not capable of removing the smear layer, but the combined use of $\mathrm{NaOCl}$ and EDTA was effective specially when EDTA was used as final irrigant, as was the case in the present work. Gambarini ${ }^{7}$ (1999) also observed this beneficial use of EDTA. These authors, however, have verified that when a tensoactive agent is combined with an increased volume of irrigating solution, the removal of the smear layer was more effective. Moreover, Bystrom, Sundqvist ${ }^{3}$ (1985) verified greater antimicrobial efficacy of $\mathrm{NaOCl}$ combined with EDTA than that of $\mathrm{NaOCl}$ alone. Since the smear layer hosts microorganisms and protects them from the action of irrigating solutions and medicaments, it is therefore necessary to remove the smear layer after canal preparation before placing the root canal dressing and obturation. The use of EDTA improved the performance of all the irrigating solutions in removing the smear layer, and promoted satisfactory cleaning of the cervical, middle and apical thirds, contrasting with the results of Takeda et al. ${ }^{14}$ (1999), who verified a poor capacity of cleaning of the apical third. 
Menezes ACSC, Zanet CG, Valera MC. Smear layer removal capacity of disinfectants solutions used with and without EDTA for the irrigating of canals: a SEM study. Pesqui Odontol Bras 2003;17(4):349-55.

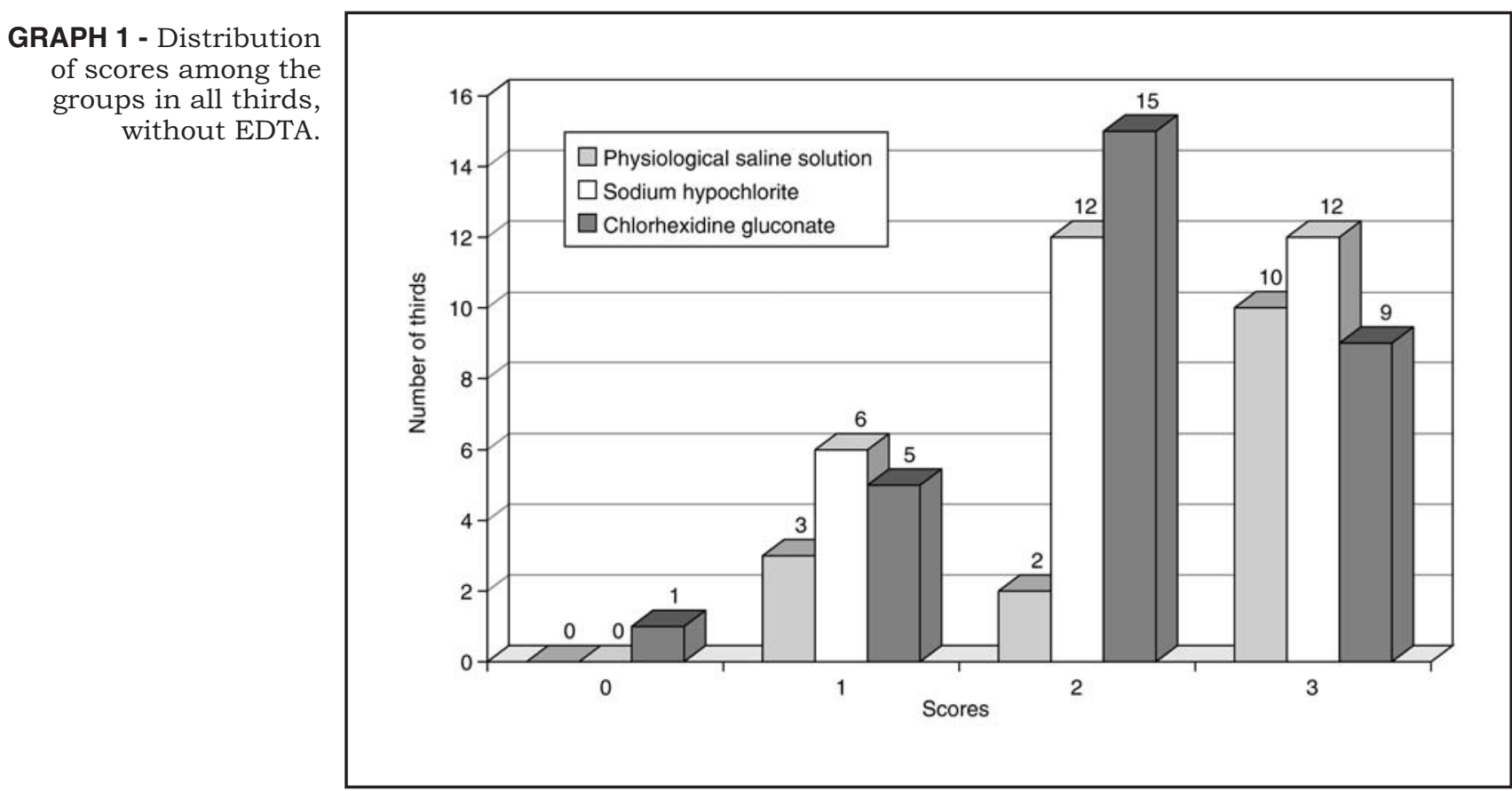

Previous studies have demonstrated that the chlorhexidine gluconate solution can be an effective endodontic irrigant. Due to its adsorption capacity and slow liberation of active cations by the dental tissues, chlorhexidine could maintain the canal free of microorganisms, even after biomechanical preparation, which results in a highly successful root canal therapy ${ }^{1,12}$. However, few studies have demonstrated the cleaning capacity of this solution.

In this work, it was verified that chlorhexidine does not remove the smear layer, and the same happens with the sodium hypochlorite solution. However, final irrigation with EDTA significantly decreased this layer.

Chlorhexidine's capacity for pulp debris removal was not verified. Ferraz et al. ${ }^{5}$ (2001) and Jeansonne, White ${ }^{9}$ (1994) showed that chlorhexidine was not capable of dissolving the pulp tissue, which is an essential property for instrumentation and preparation of teeth with pulp necrosis. $\mathrm{NaOCl}$, on the other hand, can dissolve pulp tissues, and is thus considered the irrigant of choice. According to the results of this research, the $2.0 \%$ chlorhexidine gluconate solution combined to
$17 \%$ EDTA promoted an effective cleaning of the dentin walls and can thus be used as an alternative irrigating solution due to its excellent antimicrobial activity ${ }^{9}$ in cases where patients are allergic to $\mathrm{NaOCl}$.

\section{CONCLUSIONS}

1) All irrigating solutions evaluated in this study were not effective in the elimination of the smear layer.

2) There was no difference in cleanliness of the dentin wall in the thirds evaluated, except for the $2.5 \% \mathrm{NaOCl}$ group without $17 \%$ EDTA, which presented better cleanliness in the cervical third.

3) The use of $17 \%$ EDTA improved significantly the removal of the smear layer regardless of the solution evaluated.

\section{ACKNOWLEDGEMENTS}

To the Associate Laboratory of Sensors and Material (LAS), to The National Institute for Space Research (INPE) and to The State of São Paulo Research Foundation (FAPESP) for the scientific research support \#99/10550-9. 
Menezes ACSC, Zanet CG, Valera MC. Smear layer removal capacity of disinfectants solutions used with and without EDTA for the irrigating of canals: a SEM study. Pesqui Odontol Bras 2003;17(4):349-55.

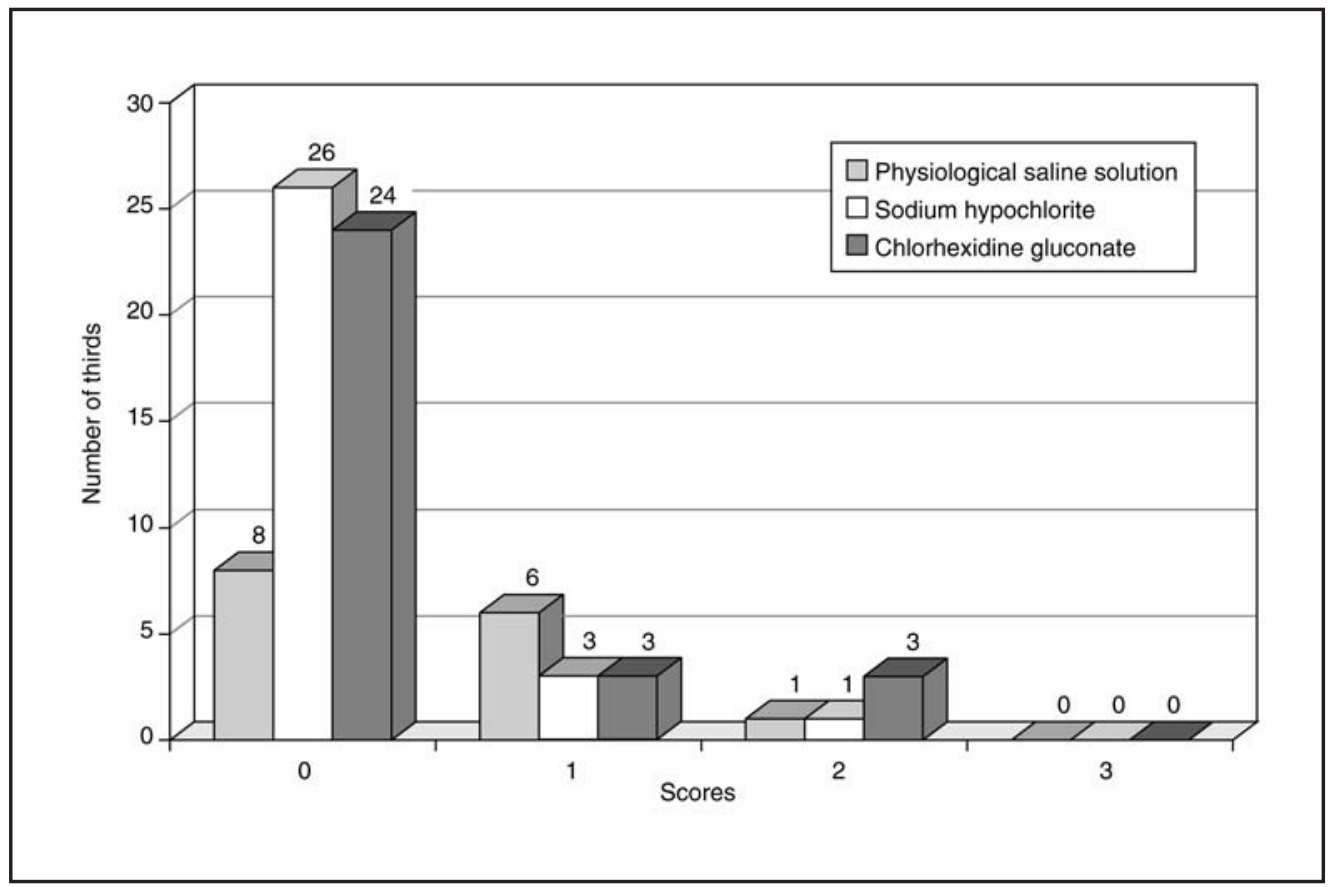

GRAPH 2 -

Distribution of scores among the groups in all thirds, with EDTA.

\section{REFERENCES}

1. Ayhan H, Sultan N, Çirak M, Ruhi MZ, Bodur H. Antimicrobial effects of various endodontic irrigants on selected microorganisms. Int Endod J 1999;32:99-102.

2. Baumgartner JC, Mader CL. A scanning electron microscopic evaluation of four root canal irrigation regimens. J Endod 1987;13:147-57.

3. Bystrom A, Sundqvist G. The antibacterial action of sodium hypochlorite and EDTA in 60 cases of endodontic therapy. Int Endod J 1985;18:35-40.

4. di Lenarda R, Cadenaro M, Sbaizero O. Effectiveness of $1 \mathrm{~mol} \mathrm{~L}^{-1}$ citric acid and 15\% EDTA irrigation on smear layer removal. Int Endod J 2000;23:46-52.

5. Ferraz CCR, Gomes BPFA, Zaia AA. In vitro assessment of the antimicrobial action and the mechanical ability of the chlorhexidine gel as an endodontic irrigant. J Endod 2001;27:452-5.

6. Franchi M, Eppinger F, Filippini GF, Montanari G. $\mathrm{NaOCl}$ and EDTA irrigating solutions for endodontics: SEM findings. Bull Group Int Rech Sci Stomatol et Odontol 1992;35:93-7.

7. Gambarini G. Shaping and cleaning the root canal system: a scanning electron microscopic evaluation of a new instrumentation and irrigation technique. J Endod 1999; 25:800-3.

8. Goldberg F, Abramovich A. Analysis of the effect of EDTAC on the dentinal walls of the root canal. J Endod 1977; 3:101-5.
9. Jeansonne MJ, White RR. A comparison of $2.0 \%$ chlorhexidine gluconate and $5.25 \%$ sodium hypochlorite as antimicrobial endodontic irrigants. J Endod 1994; 20:276-8.

10. Kennedy WA, Walker WA, Gough RW. Smear layer removal effects on apical leakage. J Endod 1986;12:21-7.

11. Kuruvilla JR, Kamath MP. Antimicrobial activity of $2.5 \%$ sodium hypochlorite and $0.2 \%$ chlorhexidine gluconate separately and combined, as irrigants. J Endod 1998; 24:472-6.

12. Leonardo MR, Tanomaru Filho M, Silva LAB, Nelson Filho $\mathrm{P}$, Bonifácio $\mathrm{KC}$, Ito IY. In vivo antimicrobial activity of $2 \%$ chlorhexidine used as a root canal irrigating solution. J Endod 1999;25:167-71.

13. Marley JT, Ferguson DB, Hartwell GR. Effects of chlorhexidine gluconate as an endodontic irrigant on the apical seal: short-term results. J Endod 2001;27:775-8.

14. Takeda FH, Harashima T, Kimura Y, Matsumoto K. A comparative study of the removal of smear layer by three endodontic irrigants and two types of laser. Int Endod $\mathrm{J}$ 1999;32:32-9.

15. Tatsuta CT, Morgan LA, Baumgartner JC, Adey JD. Effect of calcium hydroxide and four irrigation regimens on instrumented and uninstrumented canal wall topography. J Endod 1999;25:93-8.

16. White RR, Hays GL, Janer LR. Residual antimicrobial activity after canal irrigation with chlorexidine. J Endod 1997;23:229-31

Recebido para publicação em 10/07/03 Enviado para reformulação em 10/09/03 Aceito para publicação em 30/10/03 